\title{
REVIEW OF THE LEVEL OF SEXISM IN THE SERBIAN DAILY PRESS ${ }^{3}$
}

\begin{abstract}
In order to determine the level of sexism in the Serbian daily press, a survey was conducted on a corpus of three editions of daily newspapers. Relevant national print media, which differ in their editorial policy, are included in the research: Politika as a serious daily informative-political newspaper, Večernje novosti as a semi-tabloid, and Kurir as a tabloid newspaper. These dailies were chosen because of the difference in the quality of the content they offer, the readability, and therefore the greatest impact on the readership. The research was done by the method of quantitative-qualitative content analysis. The research period was chosen at random, which includes editions published on January $28^{\text {th }} 2020$. The paper applies a methodology based on the numerical scale offered by Butler-Paisley in 1976, which indicates that representations of sexism are not black and white. This scale provides an explanation of the level of sexism in the media, dividing the media coverage of women into five categories, which can be categorized with each other. The woman in the first level is so limited and incompetent, that she is not a complete person; the woman in the second level is competent, but only within the defined sphere of activity; a third-level woman is allowed a wider sphere, but only if traditional activities remain primary. The fourth level allows more freedom, saying that a woman is and must be equal to a man, and level five confirms that each individual should be viewed non-stereotypically, and that women and men can sometimes surpass each other. Despite legal regulations and legal acts, which certainly represent a framework for the protection of women's rights, the media still represent a woman under the burden of stereotypes, and do not give her enough space she deserves. The results of the research indicate certain shifts in the media representation of women, i.e. in most texts women are represented as equal to men, but there are still a large number of coded cases on the scale of "humiliate her" and "give her two places", in which the media remind us of the two-dimensional portrayal of women and the primacy of private roles, a sphere that must not be jeopardized by a professional role
\end{abstract}

Key words: daily newspapers, women, Butler-Paisley scale, sexism, stereotypes

\footnotetext{
${ }^{1}$ Received March 2020 /Accepted May 2020

${ }^{2}$ E-mail: neda.necic@filfak.ni.ac.rs

${ }^{3}$ The paper was prepared as a part of the project Tradition, Modernization and National Identity in Serbia and the Balkans in the Process of European Integration (179074), funded by the Ministry of Education, Science and Technological Development of the Republic of Serbia, and implemented by the Center for Sociological Research at the Faculty of Philosophy in Niš.
} 


\section{Introduction}

Gender equality is a condition and measure of the progress of society and the development of democracy. Although we live in a modern time, that also assumes a modern society, in Serbia the real contribution of women is still ignored, because working at home does not have the character of socially recognized work. „Discrimination is achieved through unpaid work, but also difficult professional promotion, which again marginalizes women and contributes to their poorer socioeconomic position... Such a position does not arise from some specifically female biological characteristics, but from the social role attributed to women (family responsibilities, care, household chores)" (Stjepanović - Zaharijevski, 2010: 67). The polarization of gender roles has its roots in distant history, and produces different patterns of behavior expected of men and women. Biological differences between females and males are taken as the starting point of gender stratification differences, so that women are the "other sex", while on the other hand, we have a dominant and powerful "hegemonic masculinity" (Stjepanović - Zaharijevski, 2010).

The polarization of gender roles is clearly visible in the media as well. The woman in the media is most often portrayed in the traditional way, in one of the traditional roles. These roles include a wide range of traditional behavior expected from a woman: mother or housewife, with a place in the kitchen or bedroom, with the best possible physical appearance, because apart from household chores and personal appearance, a woman should not think about anything else, except to be a decoration. "Sexism is present in media speech, especially when it comes to portraying women in positions and decision-making positions in the political, public and economic spheres... There are few media that use gender-sensitive language and thus make women invisible to the public. The so-called "Women's media" mainly deal with problems related to a woman's looks and appearance, and address women as housewives."

The roles often vary, but each of the roles aims to represent the woman in a less valuable manner compared to the representation of the man as seen in the media. "The absence of women from public, political and informational life provokes what the first theorists of law formulated as a longing for women's speech. Gender theory states that the dominant legal speech is male, as well as that the participants in the legal scene are mostly men. A woman still does not have an authentic voice to speak legally, nor a forum/academy where she can legally think like a woman, nor a social stage where a woman can legally act" (Mršević, 2011:25).

It is the media that provide information, and given their wide reach, they influence the attitudes and opinions of the audience. "The media significantly influence the formation of public opinion and through them the image of both women and gender roles is reflected. Hence, in the construction of gender identity, the media are viewed as "(social) technologies of gender" and central

\footnotetext{
${ }^{4}$ National Strategy for Gender Equality for the period from 2016 to 2020 with the Action Plan for the period from 2018 to 2020, available at: https://www.mgsi.gov.rs/lat/dokumenti/nacionalna-strategija-za -gender-equality-for-the-period-from-2016-to-2020-with-action, visited on April 22, 2020
} 
places where "discursive negotiations about gender take place" (Stjepanović Zaharijevski according to Bamburać, Jusić, Isanović, 2007: 56). Each medium has three basic roles in society: to inform, educate and entertain. Due to the impossibility to understand everything around them in a direct way, people rely on the media when getting to know the world around them. It is the media that create the image of the world. In order to bring every phenomenon or event closer to as many people as possible, the media use stereotypes in their reporting. It is known that long-term exposure to similar messages and patterns results in accepting them as true, because by repeating them, even when the consumers of the messages rationally know that they are distorted, they seem true. "The media participate in shaping the dominant views of the world, defining what is good or bad, positive or negative, moral or immoral, beautiful or ugly. Media stories, images and spectacles are made up of symbols and myths that participate in shaping personal identity as well as a shared global culture. By presenting topics, events, people, the media attributes basic meaning to women and men. The media are "central places" where discursive negotiations take place around gender, and the style and the way in which the media portray women become a kind of barometer of the cultural interpretation of the role that is given to women in society" (Sever, Andraković, 2013: 6).

The media representation of women and men is not gender sensitive, and in that way it influences the strengthening of recognizable stereotypical images of women and men. "It is clear that the media can contribute to the social construction and maintenance of gender inequalities by sending messages about where a woman belongs, defining "femininity" versus "masculinity" ("act like a woman"/"act like a man"), but also defining criteria for inclusion in these frameworks - "social gender boxes"' (Stjepanović - Zaharijevski, 2010: 146). Today's understanding of women largely depends on the media representation, which we can describe, according to Snježana Milivojević (2004), as the main media business, the process of production and exchange of meaning within a culture. The media, paraphrasing Milivojević, actually represent reality in its absence, more precisely, they recreate a certain assumption, represent an object, person or process in its/his absence. In order to recognize the general in the multitude of diversity of the phenomenal, the media reach for simplification, and so, instead of types, they offer stereotypes, instead of affirmation of diversity, they produce simplified and uncritical notions of "otherness". This simplification also reveals the permanent discomfort of the different and the new, the need to explain "others" to "ours", "differently" "known" (Milivojević, 2004: 12-13).

\section{Women and stereotypes in media representation}

Despite attempts and efforts to combat gender inequality and discrimination in the media sphere, there has been no progress. "Efforts made in the past have not led to progress in gender-sensitive reporting and non-discriminatory portrayal of 
women in the media... The media continue to express and encourage patriarchal cultural patterns and stereotyped gender roles of women and men."

The model of a woman represented by the media is, to a greater or lesser extent, a generalized representation of a woman as a mother-housewife, handsome and young, with a place in the kitchen or bedroom, where her intelligence is superfluous. "The media portray women, if at all, in the traditional way roles: housewives, mothers, and if they are employed, as clerks, or with pink collar jobs. Accordingly, there are very few, if any, descriptions of strong female personalities in responsible and authoritative positions, even at home. Similarly, women's magazines focus on "domestic" aspirations - marriage, raising children, and the like - and do not encourage education, training, and other choices that tend to place individuals in positions of power, authority, and independence. Instead, women are generally portrayed as defined by their relationships with men - suggesting that women are ultimately dependent, unable to live their own lives without "male leadership"' (Tuchman, 1978: 150). Television provides us with the information that women are most visible in afternoon culinary shows, i.e. non serious content shows. This is the case when the display exists, and an even bigger problem than this is that there is no representation where it is needed. Political topics, topics of public interest that interest the audience the most, are mostly without women as their main actors. In contrast, men dominate as interlocutors in the media, and are major actors in newspaper stories. Women are assigned less social values, reduced to physical appearance while idealizing the attributes of beauty. "The findings show that writing about women and their visual presentation, depending on the profile of the newspaper, is more or less "sexist patronage", so that projecting ingrained stereotypes challenges the process of gender role reconstruction and "the system of discourse and practice produces misogyny"' (Stjepanović - Zaharijevski, 2010: 153). Everything else, like experience, education, professional success, remains invisible, in the shadows. "Treating the female body as an object deprives it of its own identity, placing it in explicit poses and situations, reducing its functions only to instinctive and banal, is the way marketing will promote the product and attract the audience" (Lubina, Brkić Klimpak, 2014: 2016). However, the media do not only single out beauty, as a typical female value and goal, but motherhood is also advocated as the ultimate goal, without which a woman's life would be incomplete. This combination of myths about beauty and family limits the models of successful women. Therefore, on the scale of women's priorities, career and other social achievements are positioned in the "second place", and not as a necessity for self-realization. The imperative is to achieve femininity, beauty, while the importance of professional success decreases, where self-esteem is causally-consequently connected exclusively with the achievement of the mentioned imperatives. "The strategy of media representation of desirable notions about gender identities in Serbia is a strategy of excluding women, which to a large extent follows the requirements of gender construction in the function of preserving gender

\footnotetext{
${ }^{5}$ National Strategy for Gender Equality for the period from 2016 to 2020 with the Action Plan for the period from 2018 to 2020, available at: https://www.mgsi.gov.rs/lat/dokumenti/nacionalna-strategijaza -gender-equality-for-the-period-from-2016-to-2020-with-action, visited on April 22, 2020
} 
asymmetry, attributing and generating "closed" gender identities. Symbolic reality does not follow or does not recognize the achieved material equality of women, so that many successful, educated, publicly engaged women are still mostly invisible" (Stjepanović - Zaharijevski, 2010: 154).

Ad creators make extensive use of stereotypes, and thus have an impact on reinforcement of stereotypes. Erving Goffman, in his book Gender Adverisements (1979), draws attention to how women and men are portrayed in advertisements that allegedly depict scenes from "real life", while the reality that advertisers distort is also artificial in itself. As he states: "Commercial images are mostly fully exposed, "images only", at best "realistic"' (Goffman 1979: 27). He believes that advertisements do not necessarily describe how we behave as individuals, but how we think it is necessary to behave according to gender. It is these advertisements that aim to convince us that this is the right way for women and men to behave, and to direct us to the same behavior in different situations in our lives (Goffman, 1979). "When we look at gender representation in advertisements, we need to focus on advertiser stereotypes about gender differences - which are as important as stereotypes themselves are. It is not enough to just examine these stereotypes, what they can tell us about gender patterns that are largely prevalent in our society. We need to address, at least in part, how those who create (and pose for) images can design materials that are available in social situations to achieve their goal. Namely, by presenting a situation that makes sense and whose meaning can be understood in the blink of an eye" (Goffman, 1979: 27).

We can also "accuse" the advertisements for constructing a depiction of a housewife, whose main aphrodisiac is cooking, preparing and serving the family. The portrayal moves between women as unambitious, less capable, passive, talkative, gentle and sensitive. In contrast, we encounter a diametrically opposed view of men, moving between the active, the objective, the educated, the silent, the wise, and, inevitably, the dominant. All this has resulted in the audience gaining the impression that men are active, serious, dealing with important things that, among other things, are more understood than women. Thanks to such a view, their dominance and superiority is not difficult to imagine or achieve. "The media builds and establishes this inequality with many symbolic actions, from ignoring to various types of inappropriate representation. These strategies are revealed only when media messages are analyzed as systems of representation, when a common matrix is shown beneath the coincidences of the everyday" (Milivojević, 2004: 13). "And for of infinitely different stage configurations, a single ritual idiom can be revealed; behind a multitude of surface differences, a small number of structural forms" (Goffman, 1979: 27).

The power of the media, as well as the influence they have on people's attitudes, does not end with advertisements. Influence is even more important in the way of representing news, content and topics that are covered in the media space, in terms in which women appear. "The most common domain of hate speech expressed on a daily basis is the media, and hate speech cannot be justified by freedom of speech and media freedom. A special problem are the so-called live shows, live panel discussions, 
media campaigns that grow into media lynching of individual women, or phenomena related to women. It is an approach of disparaging denial of everything that is a profession. The message is addressed to all women: that they have no place on the public stage, because only those who have their own decorative erotica as an attribute can "pass" there. It is an attribute that the media never think of looking for in men on the political scene, much less to evaluate and compare it" (Mršević, 2011: 45).

The way women are portrayed in the media sends an important message to the public about their place, their role, life and position in society. "Modern media today, especially television and the Internet, are closely connected with the production of cultural identities. Namely, the conscious use and repetition of stereotypes in information recipients at a subtle level establishes the archetypal characteristics of men and women that are already socially constructed by the category of gender" (Lubina, Brkić Klimpak, 2014: 213).

\section{Previous research}

The Global Media Monitoring Project (GMMP) is the longest-running and most comprehensive study addressing the position of women in the media worldwide. The survey is conducted in all countries during one selected day. It is conducted every five years, starting in 1995. The last research was conducted in 2015 and covered Serbia as well ${ }^{6}$. The research sample included 18 news media. The first global media monitoring project and the last one from 2015, reveal that the world that is reported on is mostly male. Twenty years since the first GMMP, the challenges of sexism in the media, gender stereotypes, and gender prejudices persist in time, space, and content. "Women are still subjects in less than a quarter news 22 percent (21 percent in 2005, 28 percent in 2010 and 22 percent in 2015) in all traditional media, and in digital media they are the subjects in 20 percent of news, therefore, even slightly less than in conventional media. The structure of the news and the choice of main topics reveal the same gender insensitivity. Dominant news relates to political topics, topics related to government, crime and violence. They feature significantly fewer women who are closer to equal presentation in "non serious topics" such as news about celebrities, from the arts, the world of media and sports (44 per cent). The number of news items dedicated to women is very small (8 percent), while stories that challenge or criticize gender stereotypes and those that refer to gender equality issues are almost non-existent."

A gender-sensitive analysis of media content was conducted by Dragana Stjepanović-Zaharijevski. The Butler-Paisley scale was applied in two one-day mini-studies (2008 and 2009). The research was intended to identify different media discourses on gender by coding the representation of men and women in

\footnotetext{
${ }_{6}^{6}$ Available at: http://whomakesthenews.org/gmmp/gmmp-reports/gmmp-2015-reports, accessed 22 April 2020

7 Available at: http://centarzamedije.fpn.bg.ac.rs/ko-pravi-vesti-global-media-monitoring-2015/, accessed 22 April 2020
} 
media content. Gender-sensitive analysis of media content reveals the symbolic marginalization of women. "The general finding is that the world of men is more present in photographs and in the text in all analyzed newspapers, which has an impact on the construction of gender identities and gender relations. Men position themselves in important content, and women in entertainment engagements. In that way, the stereotypical image of gender relations is strengthened and a message is sent about the necessary maintenance of an asymmetric division of roles and spheres of action. Men wear serious themes, while women usually decorate them with prominent bodily attributes, often without a name, without a profession and their own opinion, which is certainly their degradation" (Stjepanović - Zaharijevski, 2010: 153).

Periodic analysis of content and photographs in the daily press from 2000 to 2003 was conducted by Snježana Milivojević, with the initial assumption that modern media cultivate desired notions of gender identities and roles, contributing to symbolic gender inequality. "The analysis of the roles in which women appear when they deserve media visibility reveals that in the informative press almost the same criteria apply as in the revived press. The most important female engagement is entertaining... Entertaining roles only endanger housewives - mothers, housewives, wives, companions of successful men. Professionally successful women often appear as wives and mothers, or at least they must discover their recipe for reconciling "career and family." The experts are most often psychologists, social workers, counselors for failed marriages, beauticians, counselors for nutrition and diet, doctors, teachers. Their expertise is adapted to the family sphere and the "natural" role of women to take care of the family... The range of social roles reveals a world full of opportunities for men and full of limitations for women" (Milivojević, 2004: 17).

Monitoring of the reporting of ten print media and 14 RTV stations entitled "Gender Equality in and through the Media" was conducted in 2008 in seven cities, and showed that there is discrimination against women in media reporting. The results of the research showed that women are in the central focus of the news in only $15 \%$ of cases, and the focus is mainly on celebrities and sports. Also, only one third of the news in the print media refers to women as the main subjects, and the dominant language is still stereotypical. The research showed that men appear more often, even in articles about women, that it is most often written about girls and women up to 45 years of age, and that the columns related to political events, current events, education and economy have the least news about women in all media. ${ }^{8}$

\section{Methodological framework}

The method applied in the research was quantitative-qualitative analysis of media content, and the unit of analysis was a single text. The method of content analysis, developed in the middle of the last century, is applied with the idea of observing,

\footnotetext{
${ }^{8}$ Complete report available at: https://arhiv.rosalux.rs/userfiles/files/Prirucnik_za_medije.pdf, accessed
} April 22, 2020 
describing and mostly quantitatively expressing the manifest characteristics of a message (Kleut, Mišljenović 2016: 12). More than half a century ago, Berelson defined content analysis as a technique for an objective, systematic, and quantitative description of the manifest content of communication (Berelson, 1952). The most frequently stated goals of content analysis concern conclusions about the intentions of communicators, analysis of propaganda, analysis of trends in communication, interpersonal differences in communication patterns, etc. (Popadić, Žeželj, Pavlović, 2018). The classical formula of communication "who says what, to whom, how and with what effects" best describes the aspects of the communication process that concern the conclusions drawn from the content analysis (Laswell, Lerner and Pool according to Popadić, Žeželj, Pavlović, 2018: 452). In that sense, Holsti also defines the goals of content analysis: 1) to describe the manifest characteristic of communication (what, how and to whom something was said), 2) to conclude about the antecedents of communication (why something was said) and 3) to conclude about the consequences of communication (with what effects something was said) (Holsti according to Popadić, Žeželj, Pavlović, 2018: 452).

In contentanalysis, theemphasisis on the surface characteristics of messages that have a higher degree of stability and are less susceptible to intersubjective variations. Therefore, reliability (stability, repeatability, accuracy) and validity are important in content analysis (Krippendorf according to Kleut and Mišljenović, 2016). Consequently, content analysis involves a sequence of clearly defined steps leading from theoretical considerations, through the development of research hypotheses or tasks, basic methodological decisions regarding the sample for material to be analyzed, the development of measurement strategies, to data collection, analysis and conclusions. which in turn answer the questions from which the analysis started (Popadić, Žeželj, Pavlović, 2018).

The analysis instrument was a code list, ie. the paper applies a methodology based on the numerical scale offered by Butler-Paisley in 1976, which indicates that representations of sexism are not black and white. This numerical scale concentrates on how women represented in the media are limited to specific roles and relationships. The results obtained using this scale should closely correspond to our intuitive expectations about the media, and should not conflict with the assumptions contained in the scale itself (Pingree, Hawkins, Butler, Paisley, 1976). According to this scale, it is possible to distinguish five different types of portrayal of women in the media:

1. "Humiliate her - women's presentations at this level include a stupid blonde, a sexual object or a grieving victim. Women are shown in a simplified way, as a two-dimensional image. Examples of such presentations are common in men's magazines such as Playboy, in advertisements where the female body is included as decoration, and in situations where the woman relies on others to think for her;

2. Keep her where she belongs - it can be found in all media. The traditional strengths and capabilities of women are recognized, but tradition also dictates "female" roles. Women have been shown to function well as wives, mothers, secretaries, clerks, teachers and nurses. Negative images of this level show women struggling with roles they are "not up to" (directors, 
doctors, editors, etc.) or in which they develop feminine traits;

3. Give her two places - represents the level of awareness of many "progressive" media images of women. In an entertainment program (for example a TV drama), a woman can be a lawyer or an architect, as long as dinner for her husband is on the table at six oclock. In the report, the female director is described as a grandmother, and the interview turns in the direction of her favorite recipes. A career is something that is often seen as a "supplement". Household chores and motherhood come first. The picture is that women can sometimes work professionally outside home, but they always work at home. It is possible to find such images in the media, although they are much less represented than the images of women in the previous two levels. An example of such a play is an advertisement with a woman who is a doctor of biochemistry who talks about what she gives her children for breakfast;

4. She is fully equal - it is a rarity in the portrayal of women in the media... An important difference between this and the previous level, which also allows a woman to be a professional, is that pictures of this level do not remind us that housework and motherhood are implicit jobs;

5. Non-stereotypical representation - women and men, individually, are seen as superior in their relationship in one respect, and inferior in another. The dogmatism of the fourth level (it is completely equal) is not necessary, because individuals are not evaluated on the basis of gender. The fifth level is mentioned because this scale of consciousness logically requires it, and not because level five representations can be easily found in the media" (Pingree, Hawkins, Butler, Paisley, 1976: 194-195)

Snježana Milivojević explains that the final part of the scale shows that sexism, in all types of media speech, presupposes the traditional division of labor between the sexes, and that it equally requires the portrayal of men in gender-related roles and relationships. "Mutual stereotypes preserve the patriarchal character of society and that is why their learning begins with early home TV education through popular programs. Even while memorizing simple messages from TV commercials, girls and boys receive their first lessons in media economics, but also important messages about female-male roles"(Milivojević, 2004: 21).

Relevant national print media, which differ in their editorial policy, are included in the research: Politika ${ }^{9}$ as a serious daily information-political newspaper, Večernje novosti ${ }^{10}$ as semitabloid and Informer ${ }^{11}$ as a tabloid.

\footnotetext{
${ }^{9}$ Politika is the oldest daily newspaper in the country, founded in 1904 and is considered a serious newspaper. Newspaper readers are older generations, middle-class and highly educated people. The ownership is mixed, the paper is published by Politika novine and magazines owned by the state-owned Politika AD and the Russian company East Media Group, and has national coverage. Data available at: http://serbia.mom-rsf.org/rs/mediji/detail/outlet/politika

${ }^{10}$ Vecernje novosti was created in 1953 as "vecernje" and in a semi-tabloid style, reporting on news and events that appeared during the day. The paper has national coverage Data available at: http://serbia. mom-rsf.org/rs/mediji/detail/outlet/vecernje-novosti/

${ }^{11}$ Informer is a daily newspaper founded in early 2012. According to the Association of Journalists, due
} 
These dailies were chosen because of the difference in the quality of the content they offer, the readability, and therefore the greatest impact on the readership. The research period was chosen at random, which includes editions published on January $28^{\text {th }} 2020$. A gender-sensitive analysis of media content in two one-day surveys was conducted by Dragana Stjepanović-Zaharijevski in 2008 and 2009. The Butler-Paisley scale was used in these researches, which reveals the symbolic marginalization of women. (Stjepanovic - Zaharijevski, 2010) The results of the research are expressed numerically and as a percentage.

\section{Researsh results}

In the reporting day, a total of 306 articles were published, 104 in Politika, 107 in Večernje novosti, and 95 in Informer. Of the total number of texts in all three observed papers, women were represented in 31 texts (10.13 percent), while men were represented in 147 texts (48.04 percent). There were 56 mixed texts (18.30 percent). Thus, men are four times more represented than women in the print media. Other texts were 72 (23.53 percent) (Table 1$)$.

Table 1 - Total number of published texts: number of texts in which women are presented, number of texts in which men are presented, number of texts with both women and men, and number of other texts in the dailies Politika, Večernje novosti and Infomer

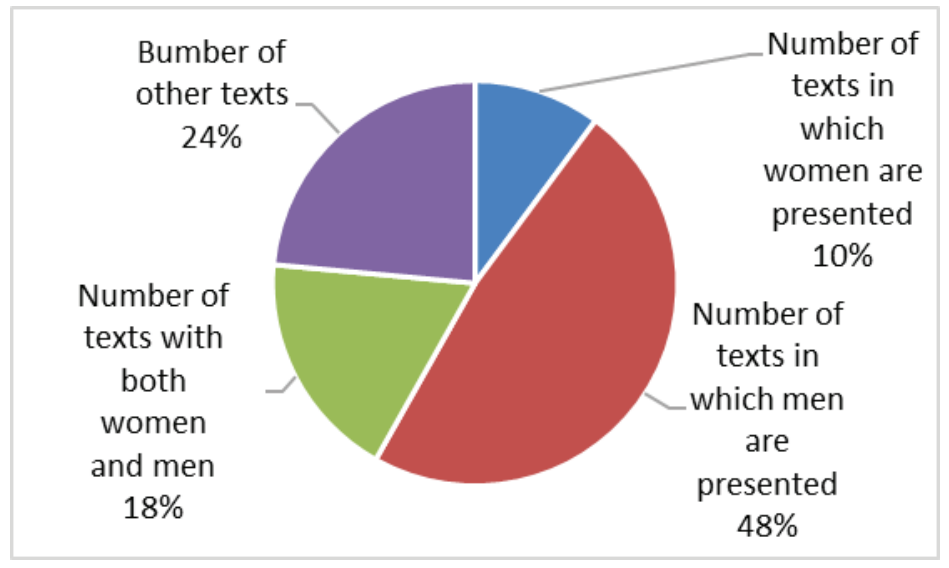

Each of the newspapers regarded individually, out of a total 104 texts in Politika, women were presented in 7 texts (6.73 percent). In the daily newspaper Večernje

to the sensationalist and tabloid type of content, it is considered one of the most unprofessional media, with the largest number of violations of the journalistic code of conduct. Ownership is private, the paper is owned by Insider Team Ltd., and has national coverage. Data available at: http://serbia.mom-rsf.org/ rs/mediji/detail/outlet/informer/ 
novosti, out of a total of 107 articles, women were presented in 8 articles (7.48 percent). In the daily Informer, out of a total of 95 articles, women were presented in 16 articles (16.84 percent). In terms of percentage, women are the most presented in the daily Informer. In Politika, men were presented in 53 articles (50.96 percent), in Večernje novosti in 47 articles (43.93 percent), and in Infomer in 47 articles (49.47 percent) (Table 2). According to these results, we can conclude that men are more present in all of the three newspapers.

Table 2 - number of articles presenting women, men and mixed articles in the dailies Politika, Večernje novosti and Infomer

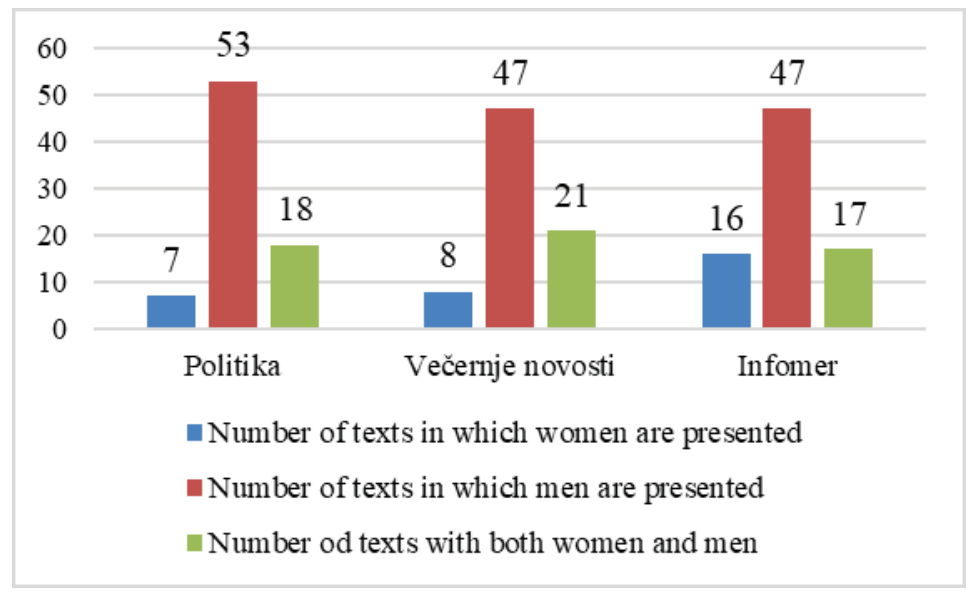

The front page of the analyzed newspaper Politika did not give place to women. On the inner pages of this paper, we have identified 25 texts, in which, using the ButlerPaisley scale, the appearance of some of the female roles were noticed. Nineteen texts were in the spirit of the representation of women as completely equal, in four texts the woman was represented completely non-stereotypically, two texts represented the woman in the category „humiliate her“. „Keep her where she belongs“, as well as "give her two places" are categories that are not identified in this paper.

The representation of women as completely equal to men is a rare occurrence in the media, but considering that this is a serious press, then that is to be expected. The category „she is completely equal“ was applied throughout the paper to texts in which women appear in their professional roles, without the necessary reminder of their domestic and maternal roles. Coded cases of „complete equality“ were found in the sections related to the world, the region, the event of the day, politics, society, culture, which is a good step towards non-stereotypical media representation of women. Some of the roles discussed are the Venezuelan vice president, MP, president, German chancellor, line minister, municipal assembly member, prime minister, director, actress, editor of an art publication, and ballet school coordinator.

The non-stereotypical representation of women was noticed in four texts, in the sections Serbia and feuilleton. According to the authors of the Butler-Paisley scale, 
this category is characterized by the emphasis personal qualities of women, regardless of gender, so the emphasis is on individual presentation, in contrast to the dogmatic reading of the obligation „a woman must be equal to a man“. The most impressive example of a non-stereotypical representation is the "Monument to the war youth by the young sculptor Natasha" (picture 1). The texts „Elena Simionesco as the prima donna of the opera in Bucharest" and "Mira Banjac, an actress from Novi Sad, who will soon present herself to the audience as a director" are also texts in which women are represented non-stereotypically. However, these texts can be found in the part of the newspaper „Reading Politika, January $28^{\text {th }} 1970$.“

The Butler-Paisley numerical scale showed two examples of the category „humiliate her", that is, two representations of women as bereaved victims, in the section of chronicles. given that this is a serious press, these are positive results, as well as the fact that there were no examples in which women are portrayed in a twodimensional, simplified image, as a sexual object.

Table 3 - Daily Politika
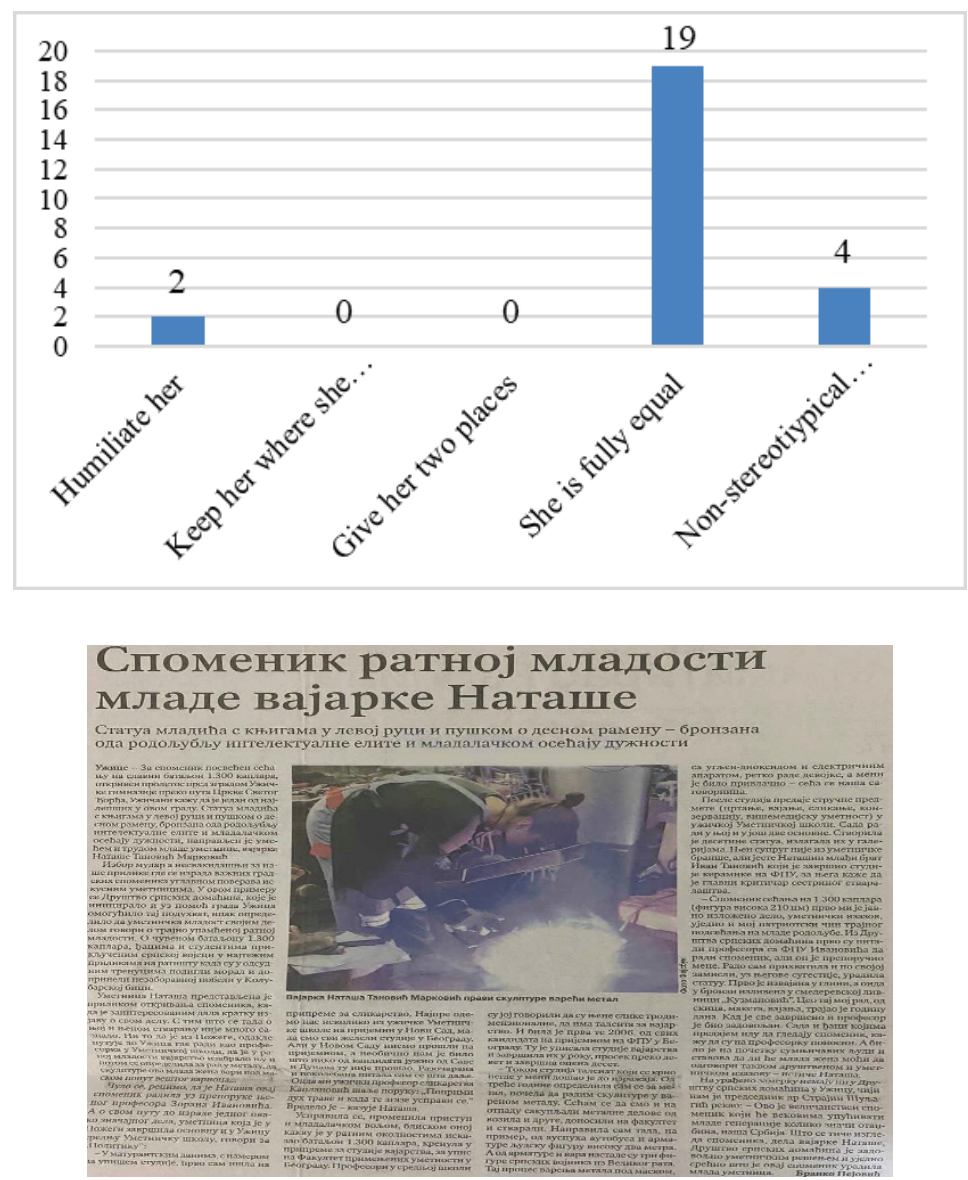

Picture 1 - January $28^{\text {th }} 2020$, Politika, page 18 . 
In most coded cases, the newspaper Večernje novosti sends information about a woman as completely equal to a man. Namely, out of a total of 30 texts in which certain roles were noticed, the woman is shown as equal to the man in 21 texts. Four texts represented women in the category „humiliate her“, in three texts women were "given two places", and there were non-stereotypical representations of women in two examples. „Keep her where she belongs“ is a category not identified in this paper. There was also no display of the woman on the front page in this paper.

In the category „women as fully equal to men“, the professional qualities of women were emphasized, in the sections politics, society, world, chronicle, reportage, and culture. At this level of the scale, women are represented as Deputy Prime Minister, Prime Minister, Director of Stonogica Primary School, Primary School Teacher, Head of Child Health, US Central Command Spokeswoman, High Court Judge, Teacher, Actress, Writer, Director of the Support Sector in representing and protecting the interests of members of the Serbian Chamber of Commerce, Secretary of the Association for Forestry, Wood Processing and Furniture and Paper Industry PKS.

In the second place, the cases are coded on the scale "humiliate her" in the sections reflector and chronicle, in four cases - most often as bereaved victims of double rape and in connection with scandals. In the text „She aimed at Filip, but she hit Milan" (January $28^{\text {th }} 2020$, Večernje novosti, page 28), our well known folk singer Zorica Marković is shown as insane because she "took a plate from the table and threw it at him".

This is followed by contents that cover up the professional success of women, as it is suppressed by information about the private life of these women by emphasizing gender roles - the category "give her two places", in the section spotlight (3 texts). In the text "We are still trying in a natural way", (January $28^{\text {th }} 2020$, Večernje novosti, page 28), pop singer Jelena Tomašević and actor Ivan Bosiljčić talk about how they want to become parents once again. Jelena Tomašević is a well-known Serbian pop singer, but the fact should not hinder her in motherhood and household. Although she is successful professionally, her private, parental life should not suffer.

The non-stereotypical representation of women was noticed in two examples, in sections reflector and Serbia: it is about the text "Charter of prof. Dr. Grujicic. Gratitude for the contribution to Serbia and the establishment of „Together for Youth“" (January 28, 2020, Vecernje Novosti, page 26). Another example is the dominance of pop star Billy Ailish at the traditional Grammy Music Awards in Los Angeles. She was awarded as the best new singer in 2019, as well as for the song and album of the year - „Domination of Billy Ailish“ (January 28, 2020, Vecernje Novosti, page 29). 
Table 4 - Večernje novosti

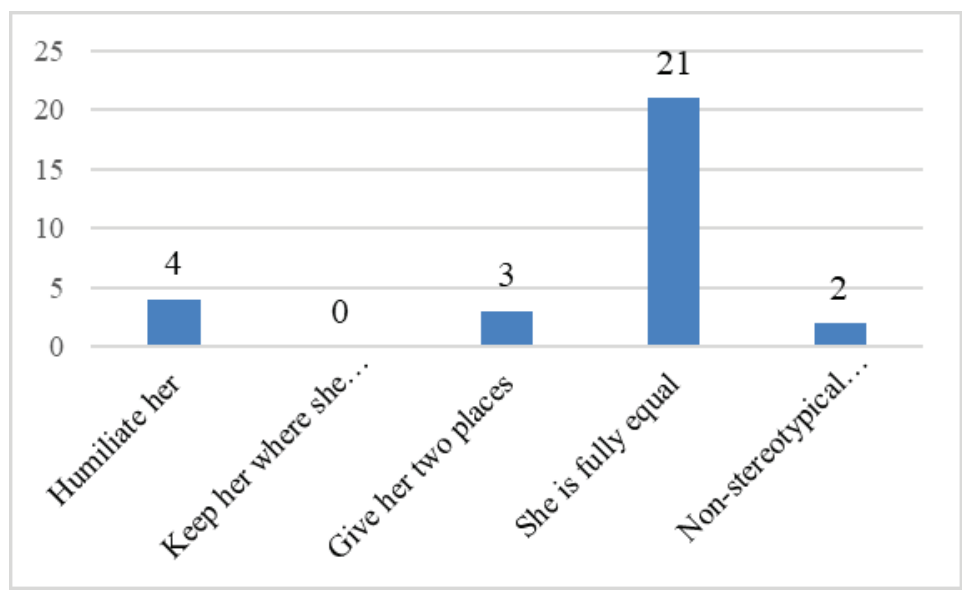

There were a total of 33 texts in the analyzed newspaper Infomer. The woman was „humiliated“ already on the front page of this paper. In relation to the analyzed newspapers, this paper identifies the largest number of coded cases on the scale „humiliate her" (15). Six texts were in the spirit of the representation of women as fully equal, five texts each belonged to the categories "give her two places" and non-stereotypical representation of women, while in two examples women were „kept where they belong“.

Examples in which a woman is "humiliated" are mostly examples of women whose roles are limited to sexual objects, grieving victims („Raped a woman in front of her boyfriend"), stupid blondes: in a word, all those contexts in which women are „humiliated“. The largest number of coded cases on the „humiliate her" scale is in the headlines, news and showtime, with women being dominant as sexual objects in the showtime section (7). The woman is already "humiliated“ on the third page, both with the text "Jovo, you are a dangerous type "and with the explicit photo that accompanies the text. The announcement from the front page "Aleksandra enters the Cooperative again to take revenge on Ana and David", as well as the text indicate that the woman is "humiliated“ by being shown as financially dependent on the man, which is confirmed by the sentence „Alexandra does not return to the Cooperative, but she ran out of money, and she doesn't want to be financed by her boyfriend anymore", as well as her explicit photo (picture 2).

In relation to other newspapers, the newspaper Informer in most cases „keeps the woman where she belongs", i.e. in traditional roles, in the columns showtime and entertainment. In these examples ( 2 examples) traditional "female" values, qualities and roles are recognized: women as housewives or mothers. „Knitting is better than meditation and yoga" (picture 3) tells all women that they will feel happier, more satisfied and more successful if they practice knitting at least three times a week. This text leads us to the conclusion that the main female aphrodisiac is knitting, which "directs" them to their primary role as housewives.

Infomer "gave the woman two places" in the showtime section, in five cases. In these examples, the media remind us that it is not important to be successful only 
professionally, but also in the household, i.e. the „basics of function“ are of great importance and should not be neglected (picture 4).

The category "she is fully equal“ was noticed in six examples, in the sections of breaking news, news and entertainment. Although this category is a rarity in the media, there have been texts in which women are represented in their professional roles, without any recollection of their domesticand maternal roles: Prime Minister, Minister for European Integration, member of the PSG presidency, general practice specialist, German chancellor.

The non-stereotypical portrayal of women was noticed in six examples, in the sections of news, showtime and entertainment. "The first programmer was a woman" (picture 5) is an example that best describes this level of scale, as well as the identified roles of directors, and „Billy Ailish picked up almost all the awards" (picture 6).

Table 5 -Infomer
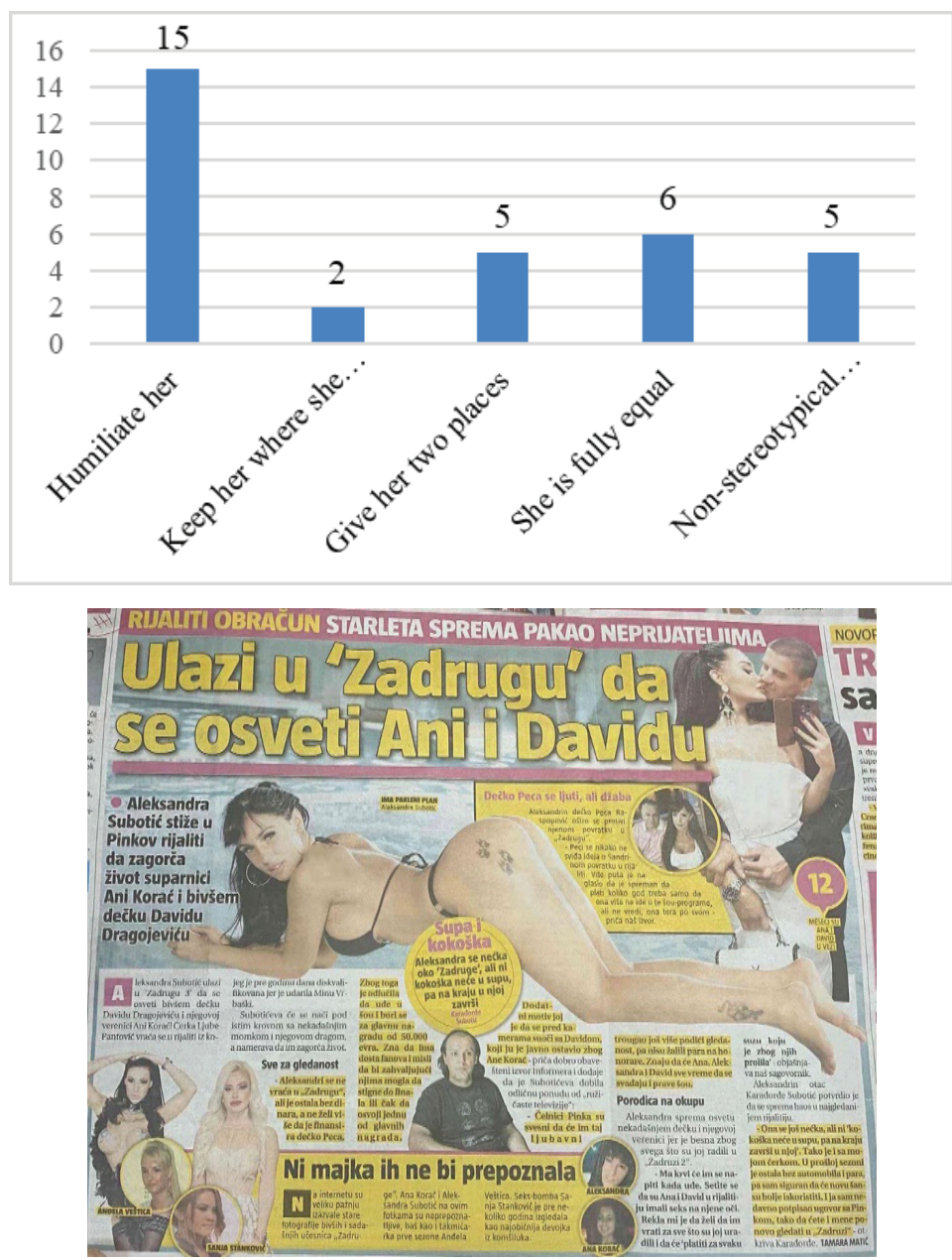

Picture 2 - January $28^{\text {th }} 2020$, Informer, page 16-17. 


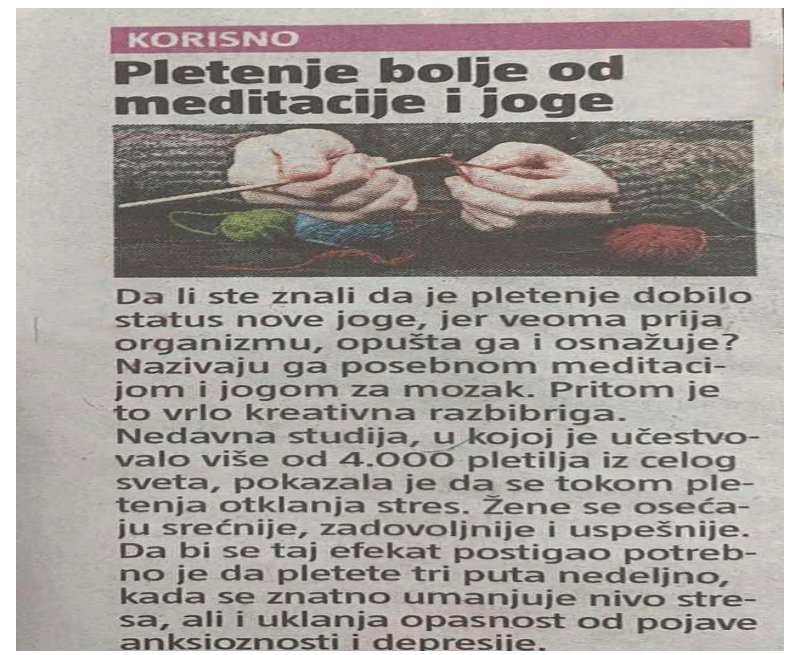

Picture 3 - January $28^{\text {th }}$ 2020, Infomer, page 22.

\section{Juitale}

Zlata Petrović kaže da većinu stvari kupuje na akcijama, posebno prašak za veš, koji na sniženju bude $i$ upola jeftiniji

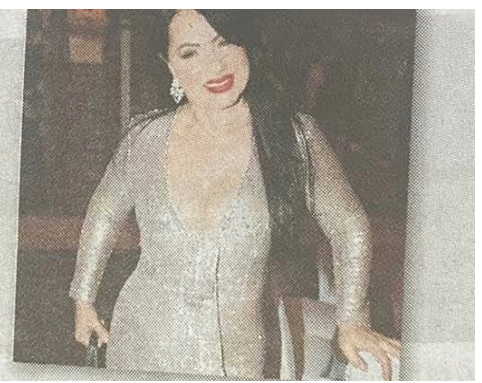

Picture 4 - January $28^{\text {th }} 2020$, Infomer, page 17.

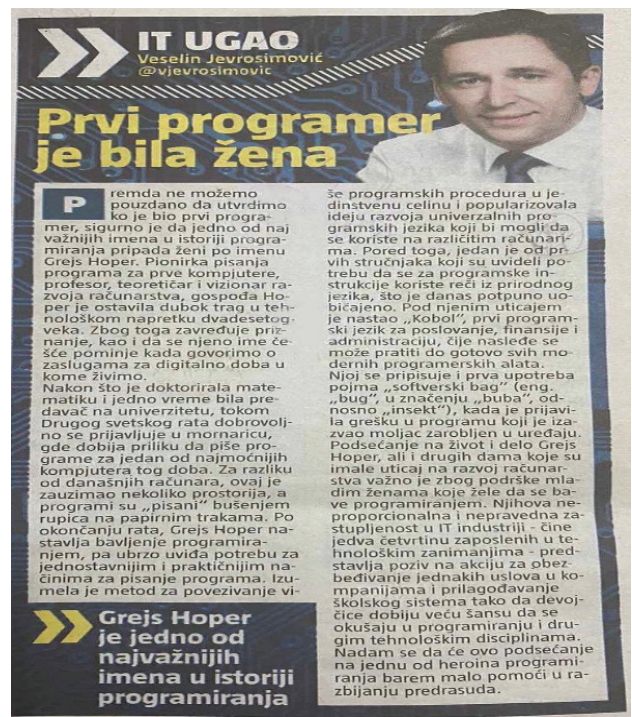

Picture 5 - January $28^{\text {th }}$ 2020, Informer, page 15 . 


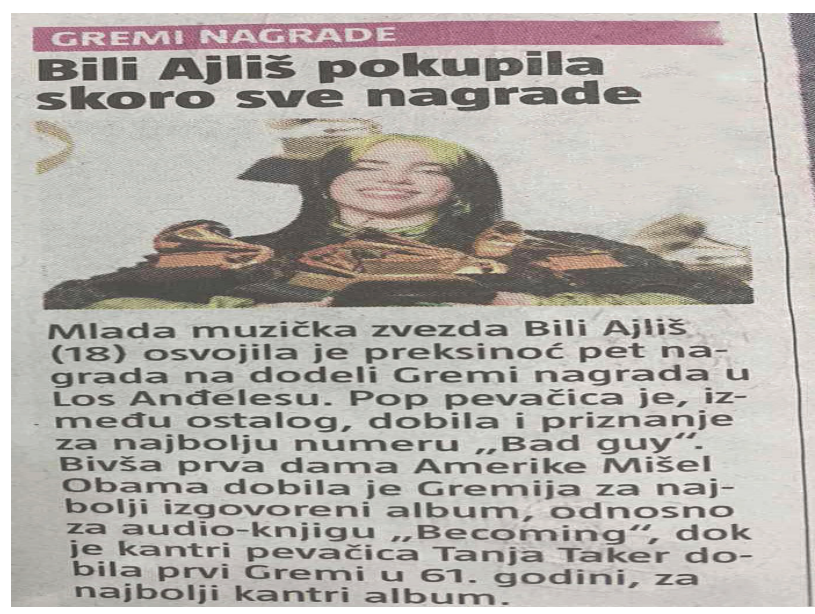

Picture 6 - January $28^{\text {th }}$ 2020, Infomer, page 18.

In the newspaper Politika, which belongs to the serious daily press, we have identified certain roles of women. Politika, in relation to the analyzed newspapers, has the largest number of coded cases (19) about women as fully equal to men. In four cases, the woman was portrayed non-stereotypically, while in two cases she was „humiliated“. The categories „keep her where she belongs“ and „give her two places“ are not registered in this daily.

In Večernji novosti, a woman is also, in most cases (21), represented as „fully equal to a man". In second place there are four cases coded on the scale as"humiliate her". Women were "given two places“ in three texts, while there was a "nonstereotypical presentation“ in two texts. The category „keep her where she belongs“, as in the case of Politika, was not not registered in this daily.

The newspaper Informer, in relation to the analyzed newspapers, has the largest number of coded cases on the scale „humiliate her“. In this paper, women were portrayed as „fully equal“ in six cases, the category of "non-stereotypical portrayal“ and "give her two places“ was in five cases, and the woman was "kept where she belongs" in two cases.

Table 6 - Social roles of women in the dailies Politika, Večernje novosti and Infomer

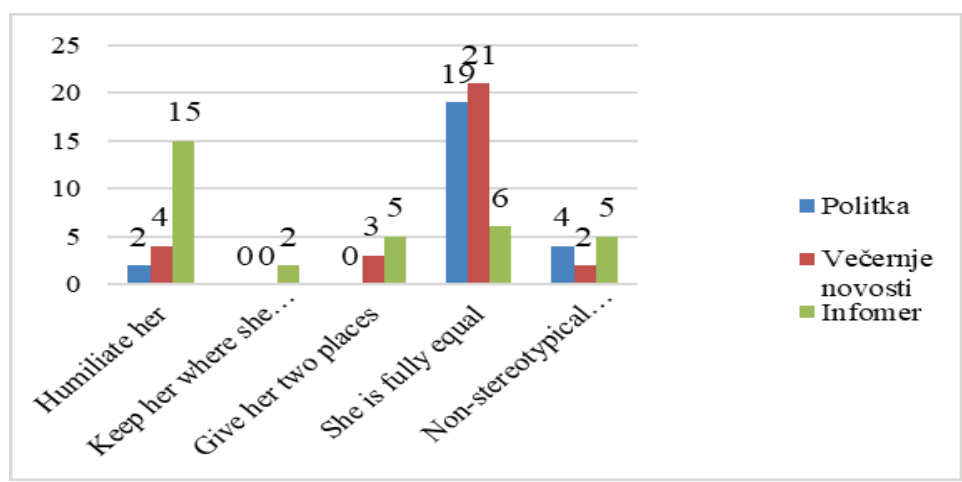




\section{Concluding considerations}

With this research, we identified that out of the total number of all published texts, it is the number 306, the representation of women was 10.13 percent, while the representation of men was 48.04 percent. Each paper individually regarded, in Politika out of 104 texts in total, women were presented in 6.73 percent, men in 50.96 percent; in Vecernji novosti, women were presented in 7.48 percent, men in 43.93 percent; in Informer, women were presented in 16.84 percent, while men were presented in 49.47 percent. These results suggest that men are more presented in all three newspapers.

The results of the gender analysis indicate that in most cases, women were identified as „fully equal“, in 46 texts (15.03 percent). In second place is the result of women as "humiliated“, in 21 texts ( 6.86 percent). It could be wrongly concluded, based on the number of coded cases "she is fully equal“, that this is the dominant portrayal of women in the Serbian daily press. If we ignore the data on the total number of posts in the analyzed day, we could conclude so. However, coded cases of women as "fully equal" constitute only 15.03 percent of the total number of texts in the analyzed day. The results indicate that the world of men is more dominant in the analyzed press. It is this result that strengthens the stereotypical image and influences the maintenance of asymmetry between gender relations. Consequently, we still cannot talk about the existence of gender equality in Serbian dailies.

Although the coded cases of women as "fully equal“ were found partly in the headlines, news, politics, most of the texts were found in the columns near the end of the list, dedicated to entertainment content such as showtime, entertainment and culture. So, in these cases, gender equality is read from the pages that are nearing the end, dedicated to entertainment content.

The media, as creators of public opinion and a mirror of society, can also be considered responsible for defining gender roles in society. Given their great influence, they should contribute to breaking down stereotypes and forming a new social matrix.

The corpus of analyzed texts is not enough to talk about the general state of media representation of female roles. We cannot interpret these results as a definitive answer. We can only assume that a larger number of copies of this newspaper would show the same or a similar result over a longer period of time.

\section{References}

Berelson, B. (1952). Content Analysis in Communication Research. Glencoes, IL: Free Press

Goffman, E. (1979). Gender Advertisements, Harper Torchbooks, New York.

Kleut, J., Mišljenović, U. (2016). Protection of privacy and presumption of innocence in the media. Belgrade: Partners for democratic change Serbia. 
Lubina, T., Klimpak Brkić, I. (2014). "Gender stereotypes: the objectifcication of a female character in the media" Quarterly Journal of Law and Social Sciences, Vol 30, No 2, pp. 213-232. URL: https://hrcak.srce.hr/130938

Milivojević, S. (2004). "Women and media: exclusionary strategies" Genero: a journal for feminist theory. Special issue, pp. 11-24. URL: https://www.fli. ba/wp-content/uploads/2016/01/Zene-i-mediji-strategija-iskljucivanjaMilivojevic-Snjezana.pdf

Mršević, Z. (2011). Towards a democratic society - gender equality. Belgrade: Institute of social sciences.

Nacionalna strategija za rodnu ravnopravnost za period od 2016. do 2020. sa Akcionim planom za period od 2018. Do 2020. godine, dostupno na: https://www.mgsi.gov.rs/lat/dokumenti/nacionalna-strategija-za-rodnuravnopravnost-za-period-od-2016-do-2020-godine-sa-akcionim, posećeno 22. aprila 2020. godine

Pingree, S., Hawkins R. P., Butler, M.,Paisley, W. (1976). "A scale for sexism” Journal of communication. Vol 26, No 4, pp. 193-201 DOI: https://doi. org/10.1111/j.1460-2466.1976.tb01958.x

Popadić, D., Pavlović, Z., Žeželj, I. (2018). Researchers tools. Belgrade: Clio.

Sever, I., Anraković, A. (2013). „Žena na javnoj televiziji“ Nova prisutnost, 11(2013)1, 5-21, URL: https://hrcak.srce.hr/98583

Tuchman, G. (1978). „The symbolic annihilation of women by the mass media“, Culture and Politics, eds. Crothers, L., Lockhart, C., 150-174, DOI: https:// doi.org/10.1007/978-1-349-62965-7

Vasiljević, Lj., Anđelković, V. (2009) Priručnik za medije. Beograd: Ženski indok cenatr URL: https://arhiv.rosalux.rs/userfiles/files/Prirucnik_za_medije.pdf

Zaharijevski S., D. (2010). Rod, identitet i razvoj. Niš: Filozofski fakultet, Punta.

Ko pravi vesti - Global Media Monitoring Project (2015). URL: http:// whomakesthenews.org/gmmp/gmmp-reports/gmmp-2015-reports

Centar za medije i medijska istraživanja URL: http://centarzamedije.fpn.bg.ac.rs/ ko-pravi-vesti-global-media-monitoring-2015/

\section{DOMINANTAN PROFIL ŽENA U SRPSKOJ ŠTAMPI}

Sažetak. Da bismo utvrdili nivo seksizma u srpskoj dnevnoj štampi, sprovedeno je istraživanje na korpusu od tri izdanja dnevnih novina. Relevantni nacionalni štampani mediji, koji se razlikuju po urađivačkoj politici uključeni su u istraživanje: Politika kao ozbiljan dnevni informativno-politički list, Večernje novosti kao polutabloid, i Kurir kao tabloidni list. Ovi dnevni listovi odabrani su zbog razlike u kvalitetu sadržaja koji nude, čitanosti, samim tim i najvećim uticajem na čitalačku publiku. Istraživanje je 
uradjeno metodom kvantitativno-kvalitativne analize sadržaja. Period istraživanja je odabran nasumično, u kojem su uključena izdanja objavljena 28.01.2020. godine. U radu se primenjuje metodologija zasnovana na numeričkoj skali koju su 1976. godine ponudile Batler-Pejsli (Butler-Paisley), a koja ukazuje da predstave seksizma nisu crnobele. Ova skala daje objašnjenje nivoa seksizma u medijima, deleći medijsko prikazivanje žena u pet kategorija, koje se mogu međusobno kategorisati. Žena u prvom nivou je toliko ograničena i nekompetentana, da nije kompletna osoba; žena u drugom nivou je kompetentna, ali samo u okviru zacrtane sfere aktivnosti; ženi trećeg nivoa dozvoljena je šira sfera, ali samo ako tradicionalne aktivnosti ostaju primarne. Četvrti nivo dozvoljava više slobode, govoreći da žena jeste i mora biti jednaka muškarcu, i nivo pet potvrđuje da svaki pojedinac treba da se posmatra nestereotipno, $i$ da se žene $i$ muškarci mogu ponekad i međusobno nadmašiti. Uprkos zakonskim propisima i pravnim aktima, koji zasigurno predstavljaju okvir za zaštitu prava žena, mediji i dalje predstavljaju ženu pod balastom stereotipa, i ne daju joj dovoljno prostora koji zaslužuje. Rezultati istraživanja ukazuju na izvesne pomake u medijskoj reprezentaciji žena, tj. u najvećem broju tekstova, žena je reprezenotvana kao jednaka muškarcu, međutim još uvek je veliki broj kodiranih slučajeva na skali "ponizi je" i "daj joj dva mesta", u kojima nas mediji podsećaju na dvodimenzinalan prikaz žena, i na primat uloge u privatnoj sferi koja ne sme biti ugrožena profesionalnom ulogom.

Ključne reči: dnevne novine, žene, skala Batler-Pejsli, seksizam, stereotipi 